\title{
Achieving a Carbon Neutral Society without Industry Contraction in the Five Major Steel Producing Countries
}

\author{
Kyunsuk Choi ${ }^{1}$, Hiroyuki Matsuura ${ }^{2}$, Hyunjoung Lee ${ }^{3, *, \dagger}$ and Il Sohn ${ }^{1, *, \dagger}$ \\ 1 Materials Science and Engineering, Yonsei University, Seoul 120-749, Korea; threecrow@naver.com \\ 2 Graduate School of Frontier Sciences, The University of Tokyo, Chiba 277-8561, Japan; \\ matsuura@k.u-tokyo.ac.jp \\ 3 Yonsei Green Institute of Technology, Yonsei University, Seoul 120-749, Korea \\ * Correspondence: mktbridge@gmail.com (H.L.); ilsohn@yonsei.ac.kr (I.S.); Tel.: +82-2-2186-8212 (H.L.); \\ $+82-2-2123-5837$ (I.S.) \\ $+\quad$ These authors contribute equally to this work.
}

Academic Editor: Marc A. Rosen

Received: 12 April 2016; Accepted: 11 May 2016; Published: 17 May 2016

\begin{abstract}
This study analyzed the direct and indirect $\mathrm{CO}_{2}$ emissions of the energy-intensive basic metals industry, in particular steels, using the distributions of various energy sources, including $\mathrm{coal} /$ peat, oil, and electricity, from an input-output table. An analysis of five major steel producing countries indicated that direct $\mathrm{CO}_{2}$ emissions increased 1.4-fold and that indirect $\mathrm{CO}_{2}$ emissions increased by more than two-fold between 1995 and 2010. The elasticity of the $\mathrm{CO}_{2}$ emissions and the total energy costs indicated that Korea, Japan, and Germany are sensitive to energy sources from the electric power industry, whereas China and the US are more sensitive to energy sources pertaining to the coal and oil industry. Using the available forest area and photosynthesis, the potential neutralization ability of $\mathrm{CO}_{2}$ was estimated using the eco- $\mathrm{CO}_{2}$ index. The US yielded the highest $\mathrm{CO}_{2}$ neutralization ability of $66.1 \%$, whereas Korea yielded a $\mathrm{CO}_{2}$ neutralization ability of $15 \%$. Future trends of the 2030 eco- $\mathrm{CO}_{2}$ index revealed China and Korea will rapidly lose their neutralization ability resulting in a net negative neutralization ability if left unabated. The significant decline in the eco- $\mathrm{CO}_{2}$ index for the basic metals industry may be inhibited by utilizing bamboo wood charcoal for pulverized coal injection (PCI) in the steelmaking process.
\end{abstract}

Keywords: $\mathrm{CO}_{2}$; input-output table; steel industry; elasticity; eco- $\mathrm{CO}_{2}$ index

\section{Introduction}

With the occurrence of unusual weather variations, natural disasters, and other sudden atmospheric catastrophes, which correlate with the increased emissions of greenhouse gases [1], there has been wide scrutiny by the international community to regulate the $\mathrm{CO}_{2}$ emissions $[2,3]$. $\mathrm{CO}_{2}$ emissions from 1990 to 2000 have increased more than ten times [4]. Because recent issues regarding the output of $\mathrm{CO}_{2}$ are expected to affect not only the natural environment but also the business environment, international effort is underway to reduce the total amount of greenhouse gas (GHG) emissions. Within the Kyoto Protocol, an agreement regarding the level of $\mathrm{CO}_{2}$ abatement for member countries, which is dependent on the degree of economic development, has attempted to enforce regulations for actual reductions in the total output of GHG. One hundred eithy-three signatories in 2008 agreed to lower the GHG produced from the use of coal, oil, and other hydrocarbon fuels [5]. Furthermore, some countries, including Korea and Norway, have implemented carbon emission trading schemes that exceed environmental regulations, which impact the economic cost structure of manufacturing industries. Thus, this study attempts to correlate the industry and $\mathrm{CO}_{2}$ 
emissions with a focus on the basic metals industry and, in particular, the steel industry, which is known to be one of the highest emitters of GHGs and consumers of energy.

The basic metals industry is the backbone of the construction, equipment, shipbuilding, and automotive industries. This industry uses multi-functional properties to provide structural support and satisfy the specific needs of consumers. In addition, steel technology development can also increase the competitiveness of affiliated industries that rely on steel materials. Thus, the steel and metals industry is considered to have a high upstream and downstream linkage effect. The facilities and production of the steel and metals industry has increased due to global economic expansion that has resulted in steel production capacities of over 1.6 billion tons in 2015 [6]. This significant increase in production capacity and steel utilization can have a positive influence on society because it creates capital value and leads to higher employment. However, the amounts of energy consumed and GHGs that are emitted during steel manufacturing also have negative implications to society, which will need to be balanced for continued sustainability. The $\mathrm{CO}_{2}$ emissions from the steel industry are generated from the blast furnace operation, where reactions between iron ore and carbon occur. Thus, recent technology developments including $\mathrm{CO}_{2}$ top gas recycling, carbon capture and storage, and hydrogen utilization to lower GHG within the blast furnace have been actively studied and implemented [7,8].

The steel and metals industry is dependent on raw materials, including ores, scrap, fossil fuels, such as coke, fluxing agents of limestone, and electrical energy. High temperatures (i.e., greater than $1823 \mathrm{~K}\left(1550^{\circ} \mathrm{C}\right)$ ) are needed to sustain the kinetics of the reaction. This energy dependence causes significant direct and indirect $\mathrm{CO}_{2}$ emissions. Two main commercial process routes exist for steel production: the blast furnace $(\mathrm{BF})$ route and the electric arc furnace $(\mathrm{EAF})$ route. The BF route is heavily dependent on fossil fuel-based energy sources, which primarily generate direct emissions, whereas the EAF route is based on scrap and electricity, which primarily generate indirect emissions. For example, the industry in China primarily uses the BF route, which constitutes $91.2 \%$ of domestic steel production; thus, direct $\mathrm{CO}_{2}$ emissions to the atmosphere are significant. Industry in Japan also tends to use the BF route but also produces steel through the EAF route, which constitutes $22.5 \%$ of domestic steel production; thus, direct and indirect $\mathrm{CO}_{2}$ emissions must be accounted for. By contrast, approximately $75 \%$ of the steel in Turkey is produced through the EAF route, which suggests that indirect $\mathrm{CO}_{2}$ emissions are significant [9].

Energy-related $\mathrm{CO}_{2}$ emissions correlated to international trade have been actively pursued by several researchers. Su and Ang discussed a multi-regional model for large countries such as China, where regional discrepancies existed depending on the development level and suggested climate policies of input and output trade to consider the regional differences [10]. Feedback effects were also considered in another work by $\mathrm{Su}$ and Ang [11]. Li et al. studied the $\mathrm{CO}_{2}$ emissions in China's iron and steel industry based on the input-output life cycle analysis suggesting improvements in the coal blending technology to increase the efficiency of the energy usage [12]. Several other works have presented analysis on the GHG intensity using input-output datasets of the respective countries [13-15]. To the knowledge of the present authors, a comparative analysis of the five major steel producing countries have yet to be done and verification of available and reliable datasets with the official statistics bureau of the individual countries are limited.

In this study, the amount of direct and indirect $\mathrm{CO}_{2}$ emissions by the basic metals-producing countries, including Korea, China, USA, Japan, and Germany, have been analyzed using the input-output table. The above-mentioned countries are the Top 5 steel producers with a cumulative $68 \%$ of the global steel production in 2014. China, Japan, USA, Korea, and Germany produce $49 \%$, $7 \%, 5 \%, 4 \%$, and 3\% of the global steel, respectively [9]. Although Russia in 2014 did produce slightly higher amounts of steel than Korea, past data for Russia were incomplete and unreliable, thus Russia was excluded within this study. The steel industry is considered to be one of the largest emitting industries of $\mathrm{CO}_{2}$ and has been chosen as the reference to compare other industries through the input-output table. In addition, this study aimed to indirectly identify the potential impact of the 
technological efforts the steel industry has made and will make with lowering $\mathrm{CO}_{2}$ emissions and in the mid to long term be utilized in providing valuable data for carbon emissions trading policies.

The steel and metals industry has one of the highest inter-industry relations index and is one of the largest emitters of GHGs, which makes it a logical choice for analysis. In addition, the arc elasticity analysis of the $\mathrm{CO}_{2}$ emissions, with regard to energy input, has been estimated to relate the sensitivity of the $\mathrm{CO}_{2}$ emissions to the total cost of the input energy sources. In addition, an eco- $\mathrm{CO}_{2}$ index that considers the neutralizing capabilities of the GHGs for steel-producing countries, using the available land mass of plant life with photosynthesis capabilities has been introduced. This study aims to provide a different perspective on the amount of $\mathrm{CO}_{2}$ emitted by countries using this eco- $\mathrm{CO}_{2}$ index and to better compare the accountabilities of countries with significant $\mathrm{CO}_{2}$ emissions.

\section{Analysis Methods and Procedures}

\subsection{Input-Output Tables Data Acquisition}

This study utilizes the modified input-output model from the input-output table, which was proposed by Leontief [16], and applies it to the amount of direct and indirect GHG emissions. The specific input-output table represents the interdependencies among industries and provides a quantitative index for comparison and the total industry relationships of all services and commodities. Each industry that constitutes a nation's economy purchases intermediate goods, including raw materials and fuels, from other industry sectors and adds labor and capital to provide new commodities and services to other industries as another intermediate good or to the final consumer. In this respect, the circulation of the national economy can be identified in terms of the national income circulation, which describes the total income from its occurrence, distribution, and disposal, and the industrial circulation, which describes the overall flow of capital goods and services among the industry production sectors. The analysis is applied and compared among the five major basic metals-producing countries, namely, Korea, China, US, Japan, and Germany.

Using the relations between the various industries and the steel industry, the available input-output table of the individual countries from 1995 to 2010 at a five-year interval was employed and correlated with the $\mathrm{CO}_{2}$ emissions of the various fossil fuel sources, including coal and peat, oil, and natural gas. The input-output table was obtained from data that were retrieved from the Organization of Economic Cooperation and Development (OECD) [17]. To expand the analysis, data that were not available from the OECD from 1995 to 2010 were obtained from the individual statistics bureaus of the relevant countries [18-22] and conformed to the items within the OECD data [17]. Although the World input-output database (WIOD), which covers the annual dataset from 1995 to 2011 was available, verification of the dataset with the individual countries statistics bureau showed significant deviations and thus the OECD data was taken to be more reliable for this particular study [23]. The input-output table data, which were provided by the OECD, are typically divided into 37 industry sectors. However, due to the omission of data for some countries, data that were not available from the OECD were adapted from the local statistics bureaus of the respective countries, which were typically divided into 26 industry sectors. Thus, the input-output table that was utilized in this study was classified into 26 separate industry sectors, as shown in Table 1 . Within the context of this work, the import assumption was based on the non-competitive import, as outlined by Su and Ang [24]. It should also be noted that industry sectors within the national input-output tables of the abovementioned countries have more than 100 classifications and according to the works of Su et al. [25] empirical studies suggest approximately 40 and above industry sectors are needed for a more accurate analysis on the $\mathrm{CO}_{2}$ emissions embodied in a particular countries exports using the input-output table. The present work is limited to the aggregated industry sector of 26 major classifications, which is lower than the 40 industry sectors specified by Su et al. [25], but the analysis and comparative data between countries should provide an informative trend and the impact of the basic metals industry with other industry sectors on the $\mathrm{CO}_{2}$ emissions. 
Table 1. 26 classified industry sectors identified. The list was simplified to correspond with the list of industry sectors defined by each individual country's local statistics bureau data (n.e.c.: not elsewhere classified).

\begin{tabular}{|c|c|c|c|}
\hline No. & Industries & No. & Industries \\
\hline 1 & Agriculture, hunting, forestry and fishing & 14 & $\begin{array}{l}\text { Motor vehicles, trailers and semi-trailers, other } \\
\text { transport equipment }\end{array}$ \\
\hline 2 & Mining and quarrying & 15 & Manufacturing n.e.c, recycling, construction \\
\hline 3 & Food products, beverages and tobacco & 16 & Electricity, gas and water supply \\
\hline 4 & Textiles, textile products, leather and footwear & 17 & Wholesale and retail trade; repairs \\
\hline 5 & Wood and products of wood and cork & 18 & Hotels and restaurants \\
\hline 6 & Pulp, paper, paper products, printing and publishing & 19 & Transport and storage \\
\hline 7 & Coke, refined petroleum products and nuclear fuel & 20 & Post and telecommunications \\
\hline 8 & Chemicals and chemical products & 21 & Finance and insurance \\
\hline 9 & Rubber and plastics products & 22 & Real estate activities \\
\hline 10 & Other non-metallic mineral products & 23 & $\begin{array}{l}\text { Machinery and equipment renting, computer } \\
\text { and related activities, other business activities }\end{array}$ \\
\hline 11 & $\begin{array}{l}\text { Basic metals, fabricated metal products except } \\
\text { machinery and equipment }\end{array}$ & 24 & Research and development, Education \\
\hline 12 & Machinery and equipment n.e.c & 25 & $\begin{array}{l}\text { Public admin. and defense, compulsory social } \\
\text { security, health and social work }\end{array}$ \\
\hline 13 & $\begin{array}{l}\text { Electrical machinery and apparatus, medical, } \\
\text { precision and optical instruments n.e.c }\end{array}$ & 26 & $\begin{array}{l}\text { Other community, social and personal services, } \\
\text { private households with employed persons }\end{array}$ \\
\hline
\end{tabular}

\subsection{Criteria for Evaluating the $\mathrm{CO}_{2}$ Emissions}

The total amount of $\mathrm{CO}_{2}$ that was emitted by the five major industrial countries is shown in Figure 1; these emissions reflect the available data between 1995 and 2010 in five-year intervals. The total $\mathrm{CO}_{2}$ emissions from the use of various energy sources were obtained from available data from the International Energy Agency (IEA) [4]. According to the IEA, the total $\mathrm{CO}_{2}$ emissions according to the energy sources are divided into five main groups, namely, coal and peat, oil, natural gas, recycled gas, and electricity. A rapid increase in the amount of $\mathrm{CO}_{2}$ emissions in China is observed from 2000 onwards. This significant increase in $\mathrm{CO}_{2}$ emissions seems to correlate with the economic boom in China, which experienced an 8\%-13\% annual increase in economic growth beginning in 2000 .

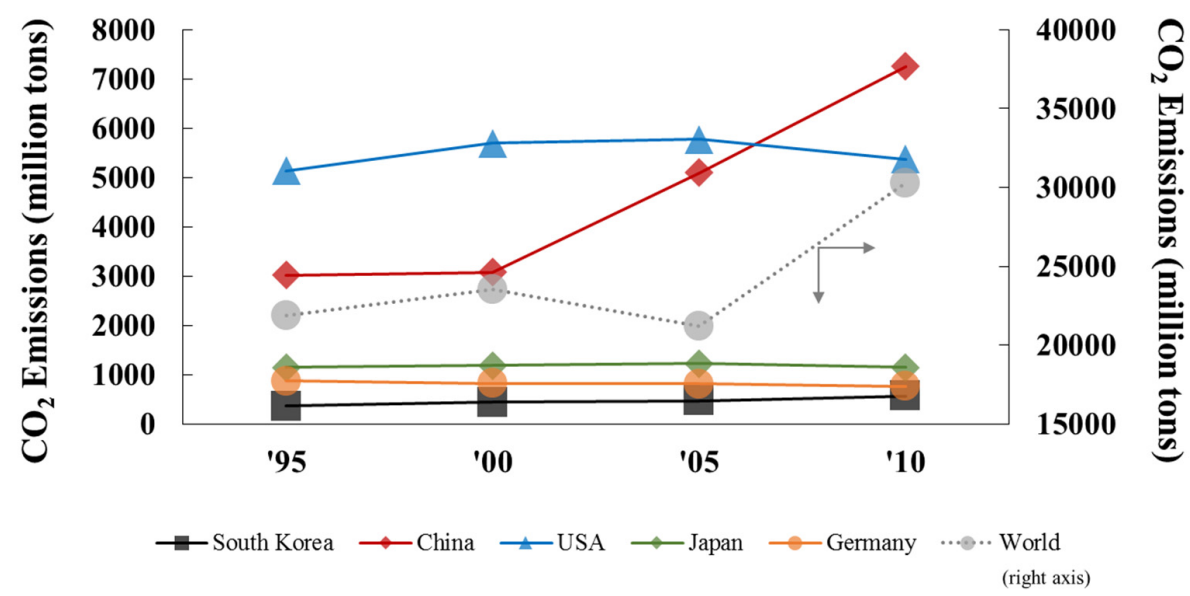

Figure 1. Total anthropogenic $\mathrm{CO}_{2}$ emissions of the five major steel producing countries taken from the IEA, which corresponds to the data available from the inter-industry relations tables from 1995 to 2010 in year intervals.

In this study, the $\mathrm{CO}_{2}$ emissions were first subdivided into the energy sources of coal/peat and oil, for which the direct $\mathrm{CO}_{2}$ emissions to the respective industry sectors were estimated from the distribution structure of these energy sources throughout these industry sectors. Because the $\mathrm{CO}_{2}$ emissions from recycled and natural gas were comparatively lower than the previously mentioned energy sources, they were not analyzed in this study. The "mining and quarrying (2)" industry 
corresponded to the production and manufacture of the energy source coal/peat, whereas the "coke, refined petroleum products and nuclear fuel (7)" sectors corresponded to the energy source oil. As shown in Figure 2, the direct emissions of each industrial sector are illustrated in (Step 1) and the indirect emissions are shown for each industrial sector in (Step 2), based on the direct emissions from the "electricity, gas and water supply (16)" sector.

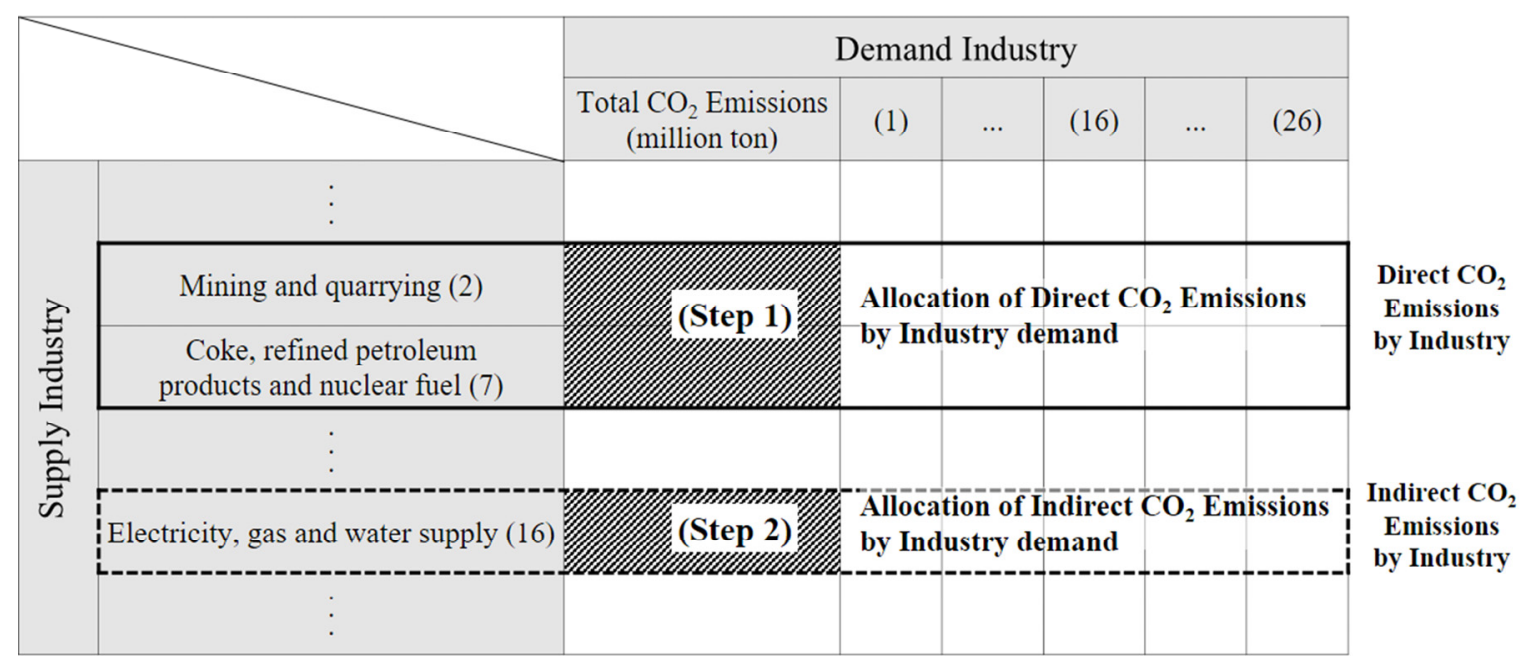

Figure 2. $\mathrm{CO}_{2}$ emissions of industry sectors divided into the direct and indirect emissions from Step 1 and Step 2, respectively.

$$
\begin{gathered}
T_{i}=E_{D}^{i}+E_{I}^{i} \\
E_{D}^{i}=\left(\frac{A_{M}^{i}}{t^{M}}\right) \times M+\left(\frac{A_{C}^{i}}{t^{C}}\right) \times C \\
E_{I}^{i}=\left(\frac{A_{E}^{i}}{t^{E}}\right) \times E
\end{gathered}
$$

Symbol and detailed description used in the equations is provided in Table 2.

Table 2. Symbol and detailed description used in the equations.

\begin{tabular}{clcl}
\hline Symbol & \multicolumn{1}{c}{ Description } & Symbol & \multicolumn{1}{c}{ Description } \\
\hline$T_{i}$ & $\begin{array}{l}\text { Total } \mathrm{CO}_{2} \text { emissions } \\
\text { from industry "I" }\end{array}$ & $A_{M}^{i}$ & $\begin{array}{l}\text { Allocated amount in USD of "Mining } \\
\text { and quarrying (2)" for industry "I" }\end{array}$ \\
\hline$E_{D}^{i}$ & $\begin{array}{l}\text { Direct emissions of } \mathrm{CO}_{2} \\
\text { from industry "I" }\end{array}$ & $A_{C}^{i}$ & $\begin{array}{l}\text { Allocated amount in USD of "Coke, } \\
\text { refined petroleum products and } \\
\text { nuclear fuel (7)" for industry "I" }\end{array}$ \\
\hline$E_{I}^{i}$ & $\begin{array}{l}\text { Indirect emissions of } \\
\mathrm{CO}_{2} \text { from industry "I" }\end{array}$ & $A_{E}^{i}$ & $\begin{array}{l}\text { Allocated amount in USD of } \\
\text { "Electricity, gas and supply (16)" for } \\
\text { industry "I" }\end{array}$ \\
\hline$M$ & $\begin{array}{l}\mathrm{CO}_{2} \text { emissions from } \\
\text { coal/peat }\end{array}$ & $t^{M}$ & $\begin{array}{l}\text { Total production price in USD of } \\
\text { "Mining and quarrying (2)" }\end{array}$ \\
\hline$C$ & $\mathrm{CO}_{2}$ emissions from oil & $t^{C}$ & $\begin{array}{l}\text { Total production price in USD of } \\
\text { "Coke, refined petroleum products } \\
\text { and nuclear fuel (7)" }\end{array}$ \\
\hline$E$ & $\begin{array}{l}\text { Direct emissions of } \\
\text { "Electricity, gas and } \\
\text { water supply (16)" }\end{array}$ & $t^{E}$ & $\begin{array}{l}\text { Total production price in USD of } \\
\text { "Electricity, gas and supply (16)" }\end{array}$ \\
\hline
\end{tabular}


Next, the $\mathrm{CO}_{2}$ emission arc elasticity was calculated to identify the sensitivity of the changes in $\mathrm{CO}_{2}$ emissions to increases in the energy input. Elasticity is commonly used in economics, which provides the tendency or sensitivity of one variable to another variable. Thus, the $\mathrm{CO}_{2}$ emission arc elasticity used in this study describes the relative change in the $\mathrm{CO}_{2}$ emissions as the amount of input costs, which varies among the various energy sources. The change in $\mathrm{CO}_{2}$ emissions due to changes in the input energy cost of industry " $I$ " according to the contributions from "mining and quarrying (2)", "coke, refined petroleum products and nuclear fuel (7)", and the "electricity, gas and water supply (16)" can be determined. The $\mathrm{CO}_{2}$ emission arc elasticity can be calculated using the following equation:

$$
\varepsilon_{i}=\left|\left(\frac{q_{i, t}-q_{i, t+1}}{p_{i, t}-p_{i, t+1}}\right) \times\left(\frac{p_{i, t}+p_{i, t+1}}{q_{i, t}+q_{i, t+1}}\right)\right|
$$

where $\varepsilon_{i}$ is the $\mathrm{CO}_{2}$ emission arc elasticity of industry " $\mathrm{I}^{\prime}, q_{i, t+1}$ is the sum of the direct and indirect $\mathrm{CO}_{2}$ emissions from industry " $\mathrm{I}$ " in time $t+1, q_{i, t}$ is the sum of the direct and indirect $\mathrm{CO}_{2}$ emissions from industry " $I$ " in time $t, p_{i, t+1}$ is the input cost of the power industry for the " $I$ " industry in time $t+1$, and $p_{i, t}$ is the input cost of the power industry for the " $I$ " industry in time $t$.

\subsection{Evaluation Criteria of the $\mathrm{CO}_{2}$ Neutralization Ability Using the eco- $\mathrm{CO}_{2}$ Index}

The neutralization capacity of $\mathrm{CO}_{2}$ from each country has been analyzed. The neutralization of $\mathrm{CO}_{2}$ is achieved by the absorption of $\mathrm{CO}_{2}$ from plant life and subsequent photosynthesis. According to the available literature, forests and plants absorb a significant amount of $\mathrm{CO}_{2}$ and re-emit oxygen via photosynthesis during the growth phases [26-28]. The growth and development of forest resources in each country provide a means for neutralizing the emitted $\mathrm{CO}_{2}$; a subsequent balance between plant life within each country and emissions may be able to provide sustainable industry growth. The $\mathrm{CO}_{2}$ neutralizing ability of forest resources has been estimated using statistics from the World Bank [29] for forest areas.

Next, the ratio of tree species within specific countries has been verified. According to studies of $\mathrm{CO}_{2}$ neutralization from forests [30], the tree species and age can have an effect on the degree of $\mathrm{CO}_{2}$ absorption, and on average the largest amounts of $\mathrm{CO}_{2}$ absorption are known to be for 20-year-old broad-leaf and needle-leaf trees at 16.1 tons/ha and 10 tons/ha, respectively. Various countries have different areas of forest resources, which cause differences in the ability of a particular country to neutralize $\mathrm{CO}_{2}$. Based on a report by the United Nations Food and Agriculture Organization (FAO) [31], the percentage of broad-leaf and needle-leaf trees in various continents and major countries is provided in Table 3.

Table 3. Percentage of tree species within the forest area for the five major industrialized countries.

\begin{tabular}{ccccc}
\hline \multirow{2}{*}{ Country } & \multicolumn{2}{c}{ Leaf Tree } & & \\
\cline { 2 - 3 } & Needle & Broad & Forest Area $\left(\mathbf{k m}^{\mathbf{2}}\right)$ & Land Area $\left.\mathbf{( k m}^{\mathbf{2}}\right)$ \\
\hline S. Korea & $42 \%$ & $58 \%$ & 62,220 & 97,230 \\
China & $48 \%$ & $52 \%$ & $2,068,606$ & $9,388,211$ \\
USA & $73 \%$ & $27 \%$ & $3,040,220$ & $9,147,420$ \\
Japan & $54 \%$ & $46 \%$ & 249,790 & 364,550 \\
Germany & $71 \%$ & $29 \%$ & 110,760 & 348,570 \\
\hline
\end{tabular}

In this study, the forest area was assumed to be covered with 20-year-old trees and the absorption amount of $\mathrm{CO}_{2}$ for the various countries with respect to the previously mentioned tree species was considered. Thus, the eco- $\mathrm{CO}_{2}$ index was calculated using Equation (5).

$$
I_{E C O}^{\mathrm{CO}_{2}}(i)=\left[1-\frac{q_{i} / f_{i}-s}{q_{i} / f_{i}}\right]
$$


where $I_{E C O}^{C O_{2}}(i)$ is the eco- $\mathrm{CO}_{2}$ index or neutralization capacity of country " $I^{\prime}, f_{i}$ is the total forestry area of country "I" (ha), $q_{i}$ is the annual total amount of $\mathrm{CO}_{2}$ emitted by country " $I$ " (ton- $\mathrm{CO}_{2}$ ), and $s$ is the amount of $\mathrm{CO}_{2}$ absorbed per 1 ha forest area (ton- $\mathrm{CO}_{2} /$ ha). It should be noted that the particular tree species that are prevalent within a certain region can affect s. Thus, the $\mathrm{I}_{E C \mathrm{O}} \mathrm{CO}_{2}(i)$ for a particular country at a value of unity describes the potential for complete neutralization of its $\mathrm{CO}_{2}$ emissions. A value of zero indicates no net ability to neutralize the $\mathrm{CO}_{2}$ that is emitted within its boundary. A negative value can also be realized when the net $\mathrm{CO}_{2}$ emissions neutralization ability of the forest area is zero and the $\mathrm{CO}_{2}$ emissions substantially exceed the net neutralization ability of the forest resources.

\section{Results and Discussion}

\subsection{Direct and Indirect $\mathrm{CO}_{2}$ Emissions}

The direct $\mathrm{CO}_{2}$ emissions from each industry sector were estimated by the proportion of energy sources, such as coal/peat and oil, utilized per industry sector in the input-output table. The total amount of $\mathrm{CO}_{2}$ that is directly emitted by the "electricity, gas and water supply (16)" sector is utilized to estimate the indirect emissions of each industry sector according to the distribution of the supplied commodity of the "electricity, gas, and water supply (16)" sector across the remaining industry sectors within the input-output table, as previously described in Step 2. As a result, the top five total $\mathrm{CO}_{2}$-emitting industry sectors, including both direct and indirect emissions, have been identified in top-down order as "coke, refined petroleum products and nuclear fuel (7)", "electricity, gas and water supply (16)", "transport and storage (19)", "chemicals and chemical products (8)", and "basic metals, fabricated metal products, with the exception of machinery and equipment (11)". If direct and indirect emissions are considered separately, the rank of direct $\mathrm{CO}_{2}$ emissions also follows the same order; however, the rank of indirect $\mathrm{CO}_{2}$ emissions was determined to be in the order of "basic metals, fabricated metal products, with the exception of machinery and equipment (11)", "public administration and defense, compulsory social security, health and social work (25)", "electricity, gas and water supply (16)", "chemicals and chemical products (8)", and "wholesale and retail trade, repairs (17)". Figure 3 provides the amount of $\mathrm{CO}_{2}$ that is emitted across the industry sectors in units of million tons, which is the average value of four time series data sets, namely, 1995, 2000, 2005, and 2010.

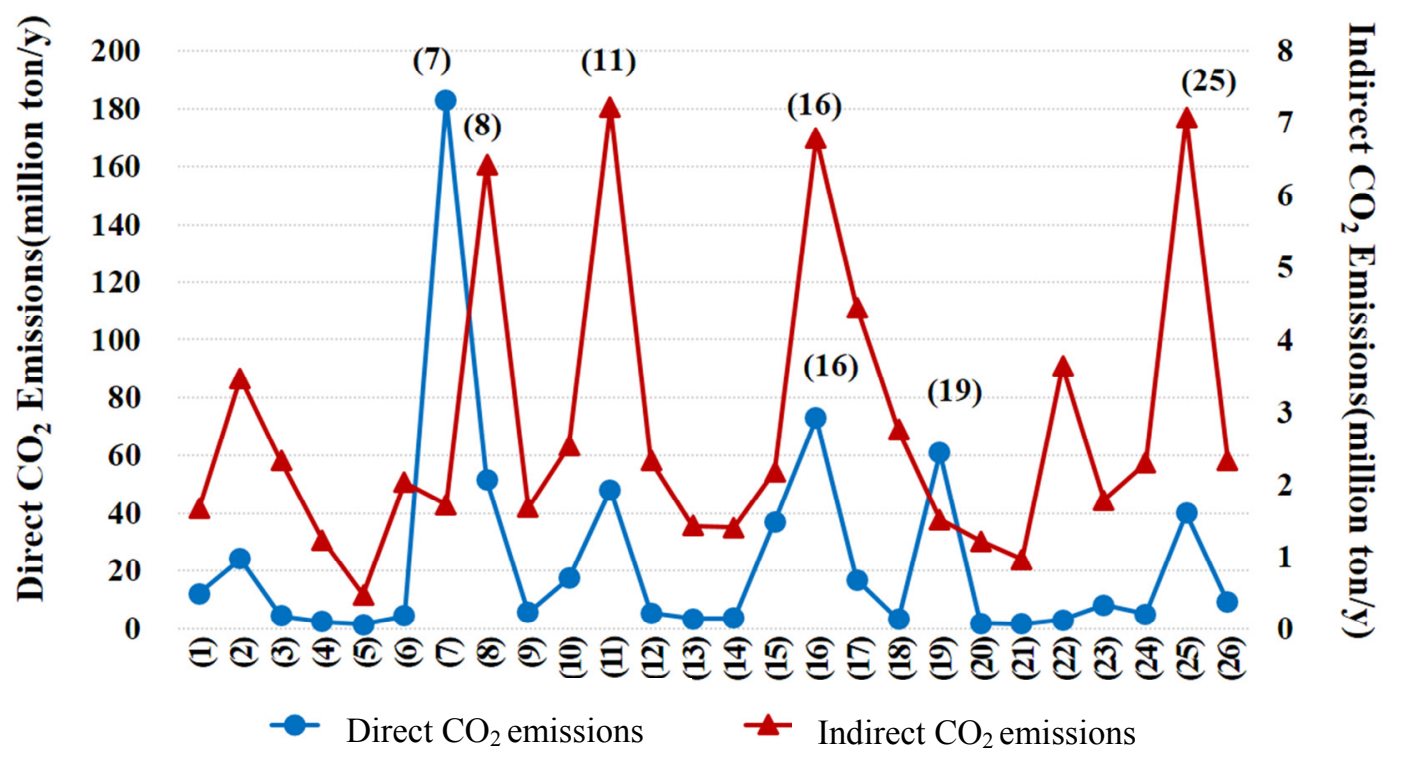

Figure 3. Average direct and indirect $\mathrm{CO}_{2}$ emissions of the industry sectors from 1995 to 2010 using data in five-year intervals. 
"Public administration and defense, compulsory social security, health and social work (25)" was ranked sixth in direct $\mathrm{CO}_{2}$ emissions but was ranked second for indirect $\mathrm{CO}_{2}$ emissions. This discrepancy is attributed to the inclusion of the defense industry in this industry sector. Due to the significant defense expenditures and allocations of capital for the countries, the role of defense in the "public administration and defense, compulsory social security, health and social work (25)" industry sector is comparatively high. A large correlation value of 0.833 ( $p$-value $<0.01$ ) was obtained between the defense expenditure and the industry sector (25) of various countries [32]. The US demonstrated the highest level of national defense spending with USD 609.9 billion in 2014, which is 17 times the level of national defense spending in Korea (USD 36 billion) and 13 times the level of national defense spending in Japan (USD 45.8 billion) [33], and emits significant amounts of $\mathrm{CO}_{2}$ from the use of various energy sources, including jet fuel and diesel, which correspond to the "coke, refined petroleum products, and nuclear fuels (7)" industry sector.

The $\mathrm{CO}_{2}$ emissions for the basic metals industry are shown in Figure 4. The direct emissions in 2010 constituted 1,183.7 million tons, which was 1.4 times the 1995 level of 856.8 million tons but which is actually lower than expected considering the increase in steel and non-ferrous metal production that the industry has observed during identical periods. The amount of indirect emissions in 2010 was 216.4 million tons, which was two times the 1995 level (107.5 million tons). The steel production in 2010 was 2.5 times the level in 1995. Production via the BF route increased 2.9 times, and production via the EAF route increased 1.6 times. The major non-ferrous metals that constitute the basic metals industry include $\mathrm{Al}, \mathrm{Cu}$, and $\mathrm{Zn}$. Global Al production in 2010 totaled more than 46 million tons compared with 19 million tons in 1995, which is a 2.5-fold increase. Cu production in 2010 was more than 20 million tons, compared with 11 million in 1995, which is a 1.8-fold increase. Zn totaled more than 12 million tons in 2010 compared with seven million tons in 1995, which is a 1.8-fold increment.

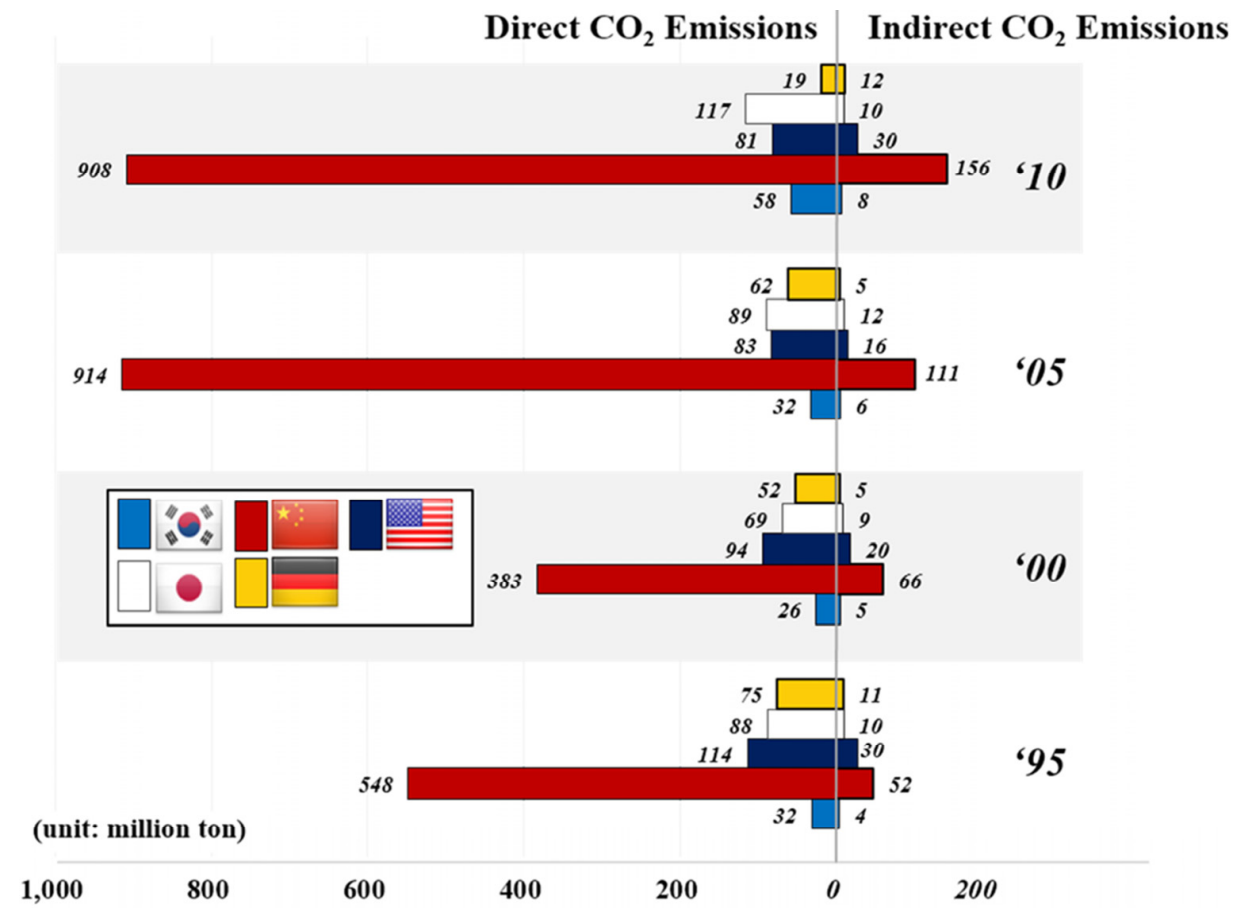

Figure 4. Average direct and $\mathrm{CO}_{2}$ emissions of the top 5 basic metals producing countries from 1995 to 2010 using data in five-year intervals.

More specifically, $\mathrm{CO}_{2}$ emissions showed a significant increase in China from 2005; the amount of $\mathrm{CO}_{2}$ that was directly emitted and indirectly emitted in 2010 was 908.34 tons and 155.73 million tons, respectively, which was 1.7 times (547.91 million tons) the 1995 level and three times (51.71 million 
tons) the 1995 level, respectively. Although the increase in the amount of direct emissions in China may be correlated with the increase in steel production via the BF process, the increase in the reduction of indirect emissions is likely to be a combination of both an increase in the production of steel via the EAF route and the processing of non-ferrous metals, such as $\mathrm{Al}, \mathrm{Cu}$, and $\mathrm{Zn}$. Al electrolytic smelting in China by the Hall-Heroult process, which consumes approximately $14,000 \mathrm{kWh} /$ ton-Al compared with $400 \mathrm{kWh} /$ ton-steel by the EAF route, produced approximately 16.2 million tons of $\mathrm{CO}_{2}$ emissions in 2010 compared with 1.78 million tons of $\mathrm{CO}_{2}$ emissions in 1995. Zinc also demonstrated a significant increase in production to 5.16 million tons of $\mathrm{Zn}$ in 2010 compared with 1.08 million tons of $\mathrm{Zn}$ in 1995. Copper exhibited a relatively steady increase compared with the substantial increases observed for $\mathrm{Al}$ and $\mathrm{Zn}$. Korea yielded direct $\mathrm{CO}_{2}$ emissions and indirect $\mathrm{CO}_{2}$ emissions of 57.9 million tons and 7.71 million tons in 2010 compared with 31.53 million tons and 4.19 million tons in 1995, respectively. Similar to China, Korea is also concentrated towards the BF route, which is heavily dependent on $\mathrm{coal} /$ peat and coke for energy and the reduction of iron ore, which produces higher levels of direct $\mathrm{CO}_{2}$ emissions. A steady increase in steel production by the EAF route of 13.89 million tons to 24 million tons from 1995 to 2010 seems to correlate with the increase in indirect $\mathrm{CO}_{2}$ emissions for Korea. The US experienced a continuous decrease in direct $\mathrm{CO}_{2}$ emissions from the basic metals industry and a decrease in indirect $\mathrm{CO}_{2}$ emissions from 1995 to 2005 and a sudden increase in these emissions in 2010: 30.5 million tons in 1995, 19.64 million tons in 2000, 16.22 million tons in 2005, and 30.43 million tons in 2010. The overall steady decrease in direct $\mathrm{CO}_{2}$ emissions in the US was attributed to the merging of steel companies and the subsequent shutdown of inefficient plants, which was replaced by the EAF route. The US has an unusually large concentration of electric arc furnaces within the steelmaking plant due to its comparatively low electricity costs and abundance of high-grade low-cost scrap. However, even with the competitive electricity costs within the US, the non-ferrous industry, including $\mathrm{Al}, \mathrm{Zn}$, and $\mathrm{Cu}$, experienced significant slowdowns and shutdowns owing to the excessively high consumption of electricity in the electrolysis of these non-ferrous basic metals. Thus, fluctuations in the indirect $\mathrm{CO}_{2}$ emissions occurred in the US because some of these non-ferrous electrolysis processes were shut down. Japan experienced an increase in direct $\mathrm{CO}_{2}$ emissions from 88.27 million tons in 1995 to 117.06 million tons in 2010. The indirect $\mathrm{CO}_{2}$ emissions seemed to remain relatively steady (10.33 million tons in 1995, 9.23 million tons in 2000, 11.78 million tons in 2005, and 10.23 million tons in 2010). Unlike the US, the price of electricity is comparatively high in Japan, which probably prevents significant capital investments in EAF production capacity and is dominated by the integrated steel mills. Although scrap costs and availability may not be prohibitive in Japan, the cost of electrical energy means that it is difficult to make the EAF process economical unless energy support is provided. In addition, large-scale non-ferrous basic metals production is limited in these high-electricity-cost regions. Germany experienced a significant decrease in $\operatorname{direct} \mathrm{CO}_{2}$ emissions from 1995 (75.48 million tons) to 2010 (19.4 million tons). Indirect $\mathrm{CO}_{2}$ emissions were 12.34 million tons in 2010, which is similar to 1995 levels. The amount of non-ferrous basic metals production in Germany was not significant within the range of this study.

Thus, it would seem that the direct emissions levels of Korea, China, and Japan are increasing along with the indirect emissions, except for Japan. This trend is correlated with the amount of steel and the non-ferrous basic metals that are produced and the dominant production route for a particular country. China, Korea, and Japan experienced production increases within the integrated steel route that utilizes coal/peat and oil as its major energy source, which yielded direct $\mathrm{CO}_{2}$ emissions. The utilization of coal and oil energy sources is speculated to be pulverized coal injection (PCI) into the blast furnace or the supplemental heat via coal or oil heating within the various steelmaking processes. Steel production by the EAF route also expanded within the time scale that was identified in this study, which generates higher amounts of indirect $\mathrm{CO}_{2}$ emissions. In addition, China experiences significant increases not only in steel production, but also in its non-ferrous sector, which is more energy-intensive per ton of metal compared with steel. Countries, such as the US, that are heavily concentrated towards the EAF route and non-ferrous metals production, in which electricity is the main energy source, will 
experience continued increases in indirect $\mathrm{CO}_{2}$ emissions. Therefore, the scheme of direct and indirect $\mathrm{CO}_{2}$ emissions in the basic metals industry is closely related to the dominant process route that is taken by the respective countries and the production amounts of major non-ferrous metals, including $\mathrm{Al}, \mathrm{Cu}$, and $\mathrm{Zn}$. Figure 5 shows the productivity of the basic metals process with direct and indirect $\mathrm{CO}_{2}$ emissions. The productivity represents the amount of produced basic metals in thousand tons with direct and indirect $\mathrm{CO}_{2}$ emissions divided by the energy costs in US million dollars. In 2010, Germany had the highest productivity of basic metals, with direct $\mathrm{CO}_{2}$ emissions of 5.23, whereas Korea had the lowest productivity of 1.50. This estimate is likely to be related to the increase in the cost of energy for Korea with respect to the other countries. For the productivity of basic metals with indirect $\mathrm{CO}_{2}$ emissions in 2010, the US had the highest productivity of 4.97, whereas Germany had the lowest productivity of 1.12. The lower value for Germany suggests a significant change in the amount of produced basic metals with respect to the other countries.

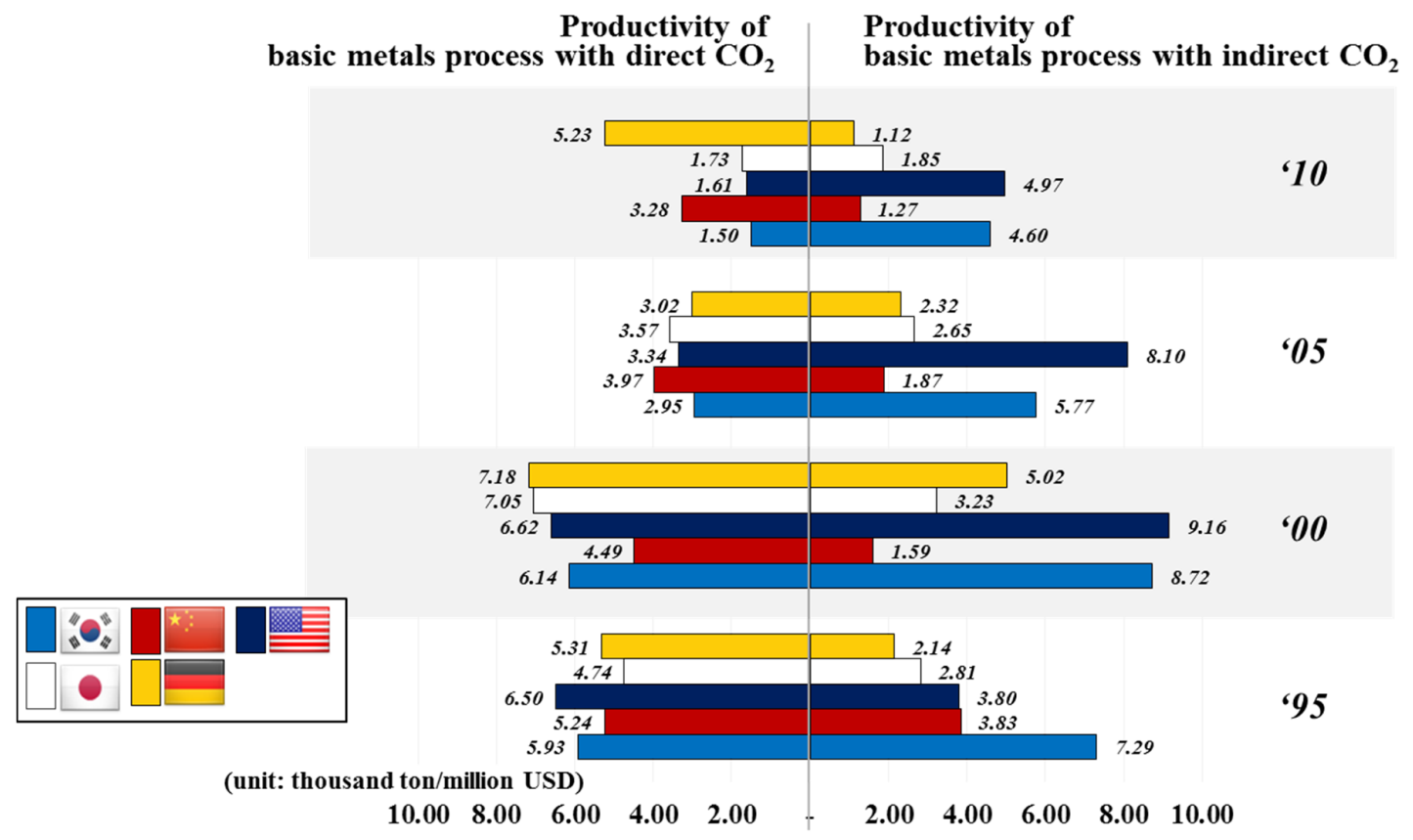

Figure 5. Productivity of the basic metals process with direct and indirect $\mathrm{CO}_{2}$ emissions for various countries from 1995 to 2010. Note the productivity is produced amount (in 1000 ton unit)/Energy input costs (in one million USD units).

\section{2. $\mathrm{CO}_{2}$ Emissions arc Elasticity}

The $\mathrm{CO}_{2}$ emissions arc elasticity was calculated to observe the changes in the total $\mathrm{CO}_{2}$ emissions with changes in the total consumption cost of the input energy sources. The arc elasticity is given as an absolute value, which describes the sensitivity of the changes in $\mathrm{CO}_{2}$ to changes in the energy costs over a defined time period. The cost of a product within a certain range can affect the amount of product demand in the demand curve, and the sensitivity of the product consumption with respect to cost can be estimated by dividing the amount of demand change with the corresponding price change. A small elasticity index indicates a low sensitivity; thus, the amount of manufactured products or $\mathrm{CO}_{2}$ emissions within this period would not be significantly affected. A large elasticity index indicates a high sensitivity; thus, the amount of $\mathrm{CO}_{2}$ emissions would significantly decrease. In this study, the elasticity of the total $\mathrm{CO}_{2}$ emissions with respect to the total consumed cost of the energy source has been considered for the five major industrial countries.

The energy sources within the basic metals industry have been identified to be the "mining and quarrying (2)", "coke, refined petroleum products and nuclear fuel (7)", and "electricity, gas and water 
supply (16)". Using available data from 1995 to 2010, the average elasticity is provided in Table 4 . An elasticity value of zero indicates perfect inelasticity, which suggests no changes in $\mathrm{CO}_{2}$ emissions with variations in the input energy cost. Daily necessities would fall within this area. An elasticity value between unity and zero indicates an inelastic behavior, in which the change in the $\mathrm{CO}_{2}$ is smaller than the changes in the input energy cost. An elasticity value of unity indicates unit elasticity, in which the amount of change in the $\mathrm{CO}_{2}$ is equivalent to the changes in the input energy cost. An elasticity value greater than the unit value indicates elastic behavior, in which the change in $\mathrm{CO}_{2}$ emissions is greater than the changes in the input energy costs. Overall, the elasticity index was not stable over the entire period. Within the 1990s, most of the countries studied showed high elasticity with coke/peat, but with time the elasticity of Electricity became pronounced. In particular, Korea, Japan, and Germany showed a high elasticity to Electricity. This could be due to the overall higher consumption or the price increase of electricity within the steel industry.

The $\mathrm{CO}_{2}$ emissions of the basic metals industry can be estimated from Equation (6). The estimated $\mathrm{CO}_{2}$ emissions indicate that Korea has a $\mathrm{CO}_{2}$ emissions increment of 3.43 million tons per one million USD in consumed input energy source costs.

$$
q_{i}=m_{\varepsilon_{i}} x_{m}+c_{\varepsilon_{i}} x_{c}+e_{\varepsilon_{i}} x_{e}
$$

where $q_{i}$ is the $\mathrm{CO}_{2}$ emissions of country " $I^{\prime}, m_{\varepsilon_{i}}$ is the elasticity factor value of industry sector (2) for country " $I$ ", $c_{\varepsilon_{i}}$ is the elasticity factor value of industry sector (7) for country " $I$ ", $e_{\varepsilon_{i}}$ is the elasticity factor value of industry sector (16) for country " $I$ ", $x_{m}$ is the input cost of industry sector (2), $x_{c}$ is the input cost of industry sector (7), and $x_{e}$ is the input cost of industry sector (16).

Table 4. Elasticity index of the Top 5 basic metal-producing countries for the period of 1995 to 2010 in five-year intervals.

\begin{tabular}{|c|c|c|c|c|}
\hline \multirow{2}{*}{\multicolumn{2}{|c|}{ Country }} & \multicolumn{3}{|c|}{ Elasticity Index } \\
\hline & & \multirow{2}{*}{$\begin{array}{l}\begin{array}{l}\text { Coke/Peat (Mining } \\
\text { and Quarrying (2)) }\end{array} \\
0.93\end{array}$} & \multirow{2}{*}{$\begin{array}{c}\begin{array}{c}\text { Oil (Coke, Refined } \\
\text { Petroleum Products } \\
\text { and Nuclear Fuel (7)) }\end{array} \\
1.14\end{array}$} & \multirow{2}{*}{$\begin{array}{c}\begin{array}{c}\text { Electricity } \\
\text { (Electricity, Gas } \\
\text { and Supply (16)) }\end{array} \\
1.36\end{array}$} \\
\hline \multirow{4}{*}{ S. Korea } & Average & & & \\
\hline & 2005-2010 & 0.79 & 0.49 & 1.46 \\
\hline & 2000-2005 & 0.51 & 0.03 & 1.93 \\
\hline & 1995-2000 & 1.50 & 2.89 & 0.69 \\
\hline \multirow{4}{*}{ China } & Average & 1.07 & 0.48 & 0.69 \\
\hline & 2005-2010 & 0.04 & 0.59 & 0.50 \\
\hline & 2000-2005 & 0.69 & 0.70 & 1.02 \\
\hline & 1995-2000 & 2.49 & 0.16 & 0.56 \\
\hline \multirow{4}{*}{ USA } & Average & 1.20 & 0.79 & 0.99 \\
\hline & $2005-2010$ & 0.79 & 2.08 & 1.64 \\
\hline & 2000-2005 & 0.63 & 0.07 & 1.01 \\
\hline & 1995-2000 & 2.17 & 0.23 & 0.34 \\
\hline \multirow{4}{*}{ Japan } & Average & 0.44 & 0.39 & 4.74 \\
\hline & 2005-2010 & 0.50 & 0.21 & 9.96 \\
\hline & 2000-2005 & 0.32 & 0.33 & 3.93 \\
\hline & 1995-2000 & 0.52 & 0.63 & 0.35 \\
\hline \multirow{4}{*}{ Germany } & Average & 0.58 & 1.02 & 1.43 \\
\hline & 2005-2010 & 0.77 & 0.84 & 2.04 \\
\hline & 2000-2005 & 0.20 & 0.28 & 0.57 \\
\hline & 1995-2000 & 0.76 & 1.95 & 1.66 \\
\hline
\end{tabular}

Specifically, Japan and Germany demonstrated a more pronounced sensitivity in $\mathrm{CO}_{2}$ emissions with higher prices in electricity as the energy source compared with China and the US, but were 
comparatively less sensitive to the total cost of coal/peat as the energy source. An elasticity index of 4.74 for Japan suggests a significant sensitivity to the electricity energy source; thus, slight changes in electricity costs can significantly affect the amount of basic metals produced and hence $\mathrm{CO}_{2}$ emissions. Japan is comparatively insensitive to the coke/peat and oil energy sources. Conversely, China and the US experienced more pronounced changes in $\mathrm{CO}_{2}$ emissions as the input total cost of the coal/peat increased. Thus, depending on the country, the changes in $\mathrm{CO}_{2}$ emissions can be affected by the dominant energy source and the concentration of the industry within a country with respect to this energy source. This situation enables the effect of a particular energy source on $\mathrm{CO}_{2}$ emissions to be closely verified and demonstrates its importance to the sustainability of the industry in terms of energy.

\subsection{Potential Neutralization Capacity of $\mathrm{CO}_{2}$}

The available forest resources and land masses within a country that emits $\mathrm{CO}_{2}$ can be effectively neutralized from the photosynthesis of plants, vegetation and forest resources. Recent studies describe the effect of global climate change due to a significant decrease in the Amazon forest vegetation and stress the importance of forest resources for carbon storage through photosynthesis [34]. This study incorporates some of the findings of previous studies of $\mathrm{CO}_{2}$ absorption rates per forest resource area and the total forest area in a country in which $\mathrm{CO}_{2}$ is emitted [35]. To simplify the calculations, agricultural areas and vegetation have been excluded from the forest area.

The $\mathrm{CO}_{2}$ neutralization ability for each country from 1995 to 2010 is shown in Table 5 in five-year intervals. The forest area, with its prominent amount of broad-leaf trees, in Korea in 2010 was 6222 thousand ha and the $\mathrm{CO}_{2}$ emission was 563 million tons. Assuming a $\mathrm{CO}_{2}$ neutralization potential of 13.54 tons per $1 \mathrm{ha}$, the neutralization ability would be $15 \%$ of the total emitted $\mathrm{CO}_{2}$. In the US, the $\mathrm{CO}_{2}$ absorption ability was estimated to be approximately 11.6 ton/ha with a neutralization ability above $66 \%$ due to its large area of needle-leaf forest resources. The concentration of manufacturing within a small land mass is attributed to this lower $\mathrm{CO}_{2}$ neutralization ability for Korea, which caused Korea to implement drastic emissions trading schemes in January 2015. These schemes will likely impede the sustainability of the steel and manufacturing industry if potential solutions to either lower $\mathrm{CO}_{2}$ or increase the neutralization abilities for the country are not improved.

Table 5. Total annual $\mathrm{CO}_{2}$ emissions, forest area, and estimated neutralization ability of the Top 5 basic-metal-producing countries for the period of 1995 to 2010 in five-year intervals. Note: A: Forest areas (thousand ha), B: $\mathrm{CO}_{2}$ emission (million ton), $\mathrm{C}$ : Eco- $\mathrm{CO}_{2}$ Index (\%).

\begin{tabular}{|c|c|c|c|c|c|c|c|c|c|c|c|c|}
\hline \multirow{2}{*}{ Country } & \multicolumn{3}{|c|}{1995} & \multicolumn{3}{|c|}{2000} & \multicolumn{3}{|c|}{2005} & \multicolumn{3}{|c|}{2010} \\
\hline & A & B & C & A & B & $\mathrm{C}$ & A & B & C & A & B & $\mathrm{C}$ \\
\hline S. Korea & 6329 & 358.6 & 23.9 & 6288 & 437.7 & 19.4 & 6255 & 469.1 & 18.1 & 6222 & 563.0 & 15.0 \\
\hline China & 167,071 & 3022.1 & 72.5 & 177,001 & 3077.2 & 75.5 & 193,044 & 5103.1 & 49.6 & 206,861 & 7258.6 & 37.4 \\
\hline USA & 298,265 & 5138.7 & 67.8 & 300,195 & 5698.1 & 61.5 & 302,108 & 5771.7 & 61.1 & 304,022 & 5368.5 & 66.1 \\
\hline Japan & 24,913 & 1147.9 & 27.8 & 24,876 & 1184.0 & 26.9 & 24,935 & 1220.7 & 26.2 & 24,979 & 1310.4 & 24.4 \\
\hline Germany & 10,909 & 867.8 & 14.8 & 11,076 & 825.0 & 15.8 & 11,076 & 809.0 & 16.1 & 11,076 & 761.6 & 17.1 \\
\hline
\end{tabular}

A time series analysis was performed to estimate the average $\mathrm{CO}_{2}$ neutralization ability, in which the neutralization potential was used as the dependent variable and the forest area and $\mathrm{CO}_{2}$ emissions were used as the independent variables. Thus, future estimates from the time-series analysis consider the variation factors and analyze the dynamic relationship of the serial correlation among the time-series data. The variation for a specified time is affected by previous changes or previous errors (white noise). The Auto-Regressive Integrated Moving Average (ARIMA) model utilizes this relationship in the following equation

$$
\mathrm{Y}_{\mathrm{t}}(\mathrm{p}, \mathrm{d}, \mathrm{q})=\phi_{0}+\phi_{1} \times \Delta \mathrm{d} \times \mathrm{Y}_{\mathrm{t}-1}+\ldots+\phi_{\mathrm{p}} \times \Delta \mathrm{d} \times \mathrm{Y}_{\mathrm{t}-\mathrm{p}}+\theta_{1} \times \varepsilon_{\mathrm{t}-1}-\ldots-\theta_{\mathrm{q}} \times \varepsilon_{\mathrm{t}-\mathrm{q}}+\varepsilon_{\mathrm{t}}
$$


where $\varepsilon_{\mathrm{t}}$ represent mutually independent average values, which sum to 0 , and the fixed variance exhibits a normal distribution. Thus, $\varepsilon_{\mathrm{t}}$ is white noise, and $\phi_{0} \ldots \phi_{\mathrm{p}}$ and $\theta_{1} \ldots \theta_{\mathrm{q}}$ are undetermined parameters. The ARIMA analysis identifies the dynamic characteristics of the time-series data and enables relatively accurate estimates, which are broadly applied to stock markets, economics, and resource management. This study also attempted to estimate future trends of the $\mathrm{CO}_{2}$ neutralization potential of various countries using the ARIMA model. The ARIMA model consists of three parts and is expressed as ARIMA (p, d, q), where $p$ is the order of the regression analysis, $d$ is the order of the differentiation, and $\mathrm{q}$ is the order of the moving average. The effective model equations for estimating the dependent variable are provided in Table 6.

Table 6. Parameter estimation of eco- $\mathrm{CO}_{2}$ index.

\begin{tabular}{|c|c|c|c|c|c|}
\hline Country $(p, d, q)$ & Model & Estimation & $t$-value & Significant & $\begin{array}{c}\text { Model Fit Statistics } \\
\text { Adjusted } \mathbf{R}^{2}\end{array}$ \\
\hline \multirow{3}{*}{$\begin{array}{l}\text { South Korea } \\
\qquad(0,1,0)\end{array}$} & Constant & 0.114 & 0.525 & 0.692 & \multirow{3}{*}{0.928} \\
\hline & $\mathrm{CO}_{2}$ emission & $-2.27 \times 10^{-10}$ & -0.678 & 0.621 & \\
\hline & Forest Areas & $3.84 \times 10^{-7}$ & 0.621 & 0.646 & \\
\hline \multirow{3}{*}{ China $(0,1,0)$} & Constant & 1.070 & 0.895 & 0.535 & \multirow{3}{*}{0.875} \\
\hline & $\mathrm{CO}_{2}$ emission & $-0.86 \times 10^{-10}$ & -1.207 & 0.440 & \\
\hline & Forest Areas & $4.72 \times 10^{-10}$ & 0.058 & 0.963 & \\
\hline \multirow{3}{*}{ USA $(0,1,0)$} & Constant & 0.743 & 11.693 & 0.054 & \multirow{3}{*}{0.847} \\
\hline & $\mathrm{CO}_{2}$ emission & $-1.17 \times 10^{-10}$ & -63.534 & 0.010 & \\
\hline & Forest Areas & $1.80 \times 10^{-9}$ & 8.196 & 0.077 & \\
\hline \multirow{3}{*}{ Japan $(0,1,0)$} & Constant & 0.514 & 0.749 & 0.591 & \multirow{3}{*}{0.991} \\
\hline & $\mathrm{CO}_{2}$ emission & $-2.06 \times 10^{-10}$ & -11.842 & 0.054 & \\
\hline & Forest Areas & $0.40 \times 10^{-11}$ & 0.001 & 0.921 & \\
\hline \multirow{3}{*}{ Germany $(0,1,0)$} & Constant & 0.260 & 8.524 & 0.074 & \multirow{3}{*}{0.913} \\
\hline & $\mathrm{CO}_{2}$ emission & $-2.06 \times 10^{-10}$ & -43.665 & 0.015 & \\
\hline & Forest Areas & $6.19 \times 10^{-9}$ & 2.500 & 0.242 & \\
\hline
\end{tabular}

The coefficient of determination that describes the suitability of the model was determined to be greater than 0.90 [36]. The coefficients of determination near zero suggest a low usefulness of the model, whereas a higher value near 1 suggests a high usefulness of the model. Using available data to 2010 limits the accuracy of estimates and trends. Within this estimate, the emitted $\mathrm{CO}_{2}$ negatively affects the neutralization and the forest area positively affects the neutralization. For China, the neutralization ability seems to decrease even when the forest area increases. These results are attributed to the rate of industrial expansion and the rate of increase in $\mathrm{CO}_{2}$ emissions, which substantially exceeds the increments of forest areas that are set within the estimates. This finding corresponds to the rate at which the $\mathrm{CO}_{2}$ emissions are increasing within China and its effective ability to neutralize its $\mathrm{CO}_{2}$ emissions. For Korea, the $\mathrm{CO}_{2}$ neutralization ability has seen a significant decrease since 1995, and the constant of the model yields a negative value. However, if the forest area were to increase in Korea then this country could achieve greater improvements in neutralization ability compared with other countries. Thus, the capacity for Korea's neutralization ability to improve with forest farming and expansion of its forest area may be sufficient. The estimated neutralization ability from 2015 to 2030 in five-year intervals from the analysis of the ARIMA model is provided in Figure 6. This estimate accounts for the dynamic changes of the forest area and $\mathrm{CO}_{2}$ emissions in terms of time for a particular country. Korea, China, and Japan show a decrease in the estimated $\mathrm{CO}_{2}$ neutralization ability, whereas Germany and the US appear to have a neutralization ability that will remain stagnant or slightly increase. Korea and China both show a steep decline in the neutralization ability for the actual and estimated values. If the forest area remains constant or decreases, the neutralization ability of the country will become negative with a total loss of neutralization capacity. Conversely, the slight increases in the neutralization potentials for Germany and the US are attributed to its trend in lower $\mathrm{CO}_{2}$ emissions and increases in forest area. 


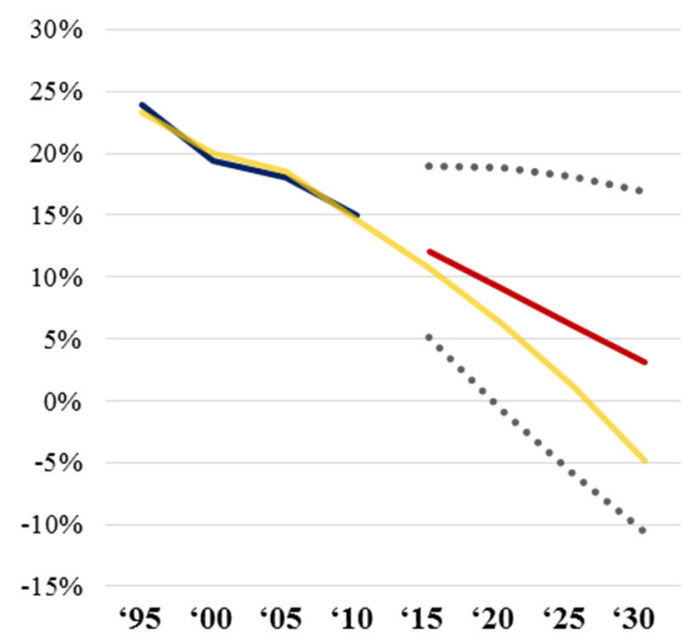

(a)

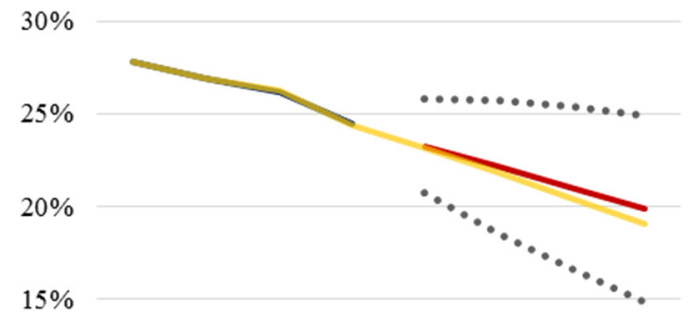

$10 \%$

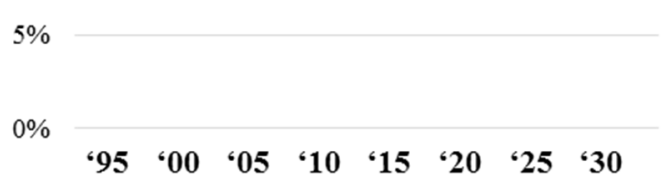

(d)

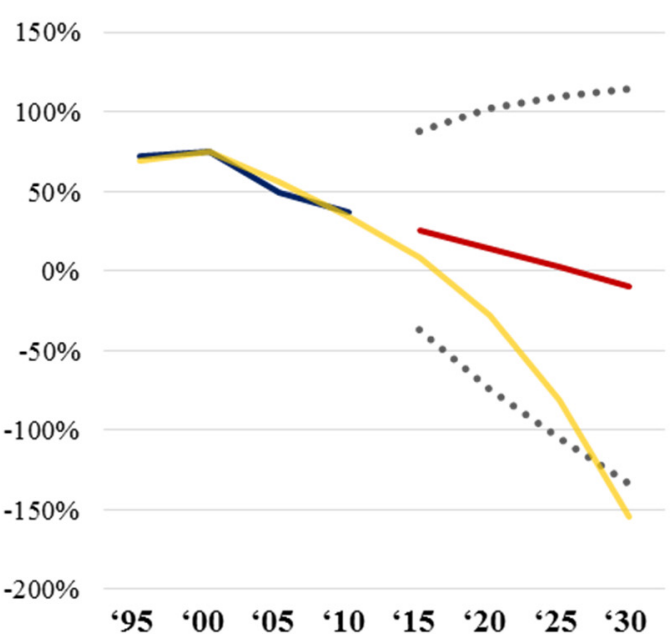

(b)

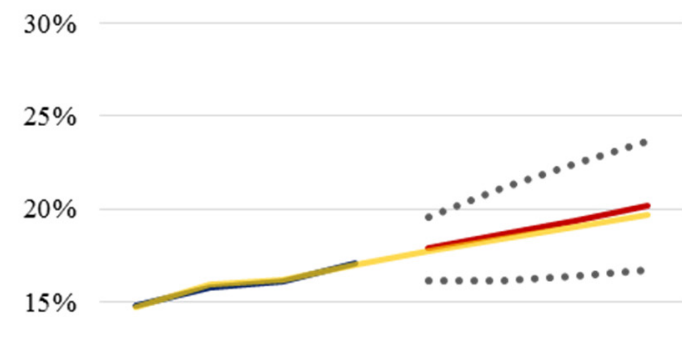

$10 \%$

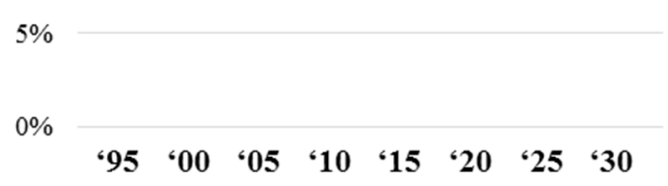

(e)

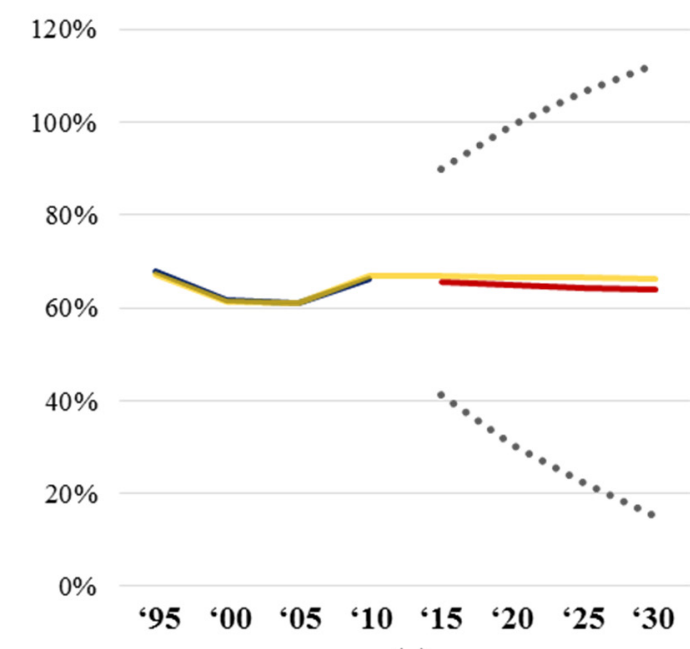

(c)

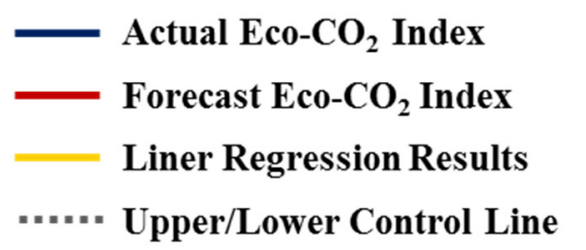

Figure 6. Eco- $\mathrm{CO}_{2}$ Index with the estimated forecast using the ARIMA model up to 2030. (a) South Korea; (b) China; (c) USA; (d) Japan; (e) Germany. 


\subsection{Possible Scenario to Increase $\mathrm{CO}_{2}$ Neutralization}

A potential scenario has been provided, in which controlled industry expansion is possible without significant industry contraction if forest resources can be effectively utilized. Using Korea as an example country and bamboo forest farming as a tree species to be used, the annual $\mathrm{CO}_{2}$ neutralization of rapidly growing trees has been measured to be between 29 and 47 ton- $\mathrm{CO}_{2} /$ ha [30,37-40]. Studies have shown that bamboo species can grow in excess of $30 \mathrm{~cm}$ per day [41]. After a five-year period, these bamboo trees can also be utilized as carbon sources as bamboo charcoal, which may replace some of the fixed carbon that is used for fuel, and would be considered to be carbon neutral.

Approximately $20 \%$ of the bamboo charcoal with respect to its initial weight can be produced. Because approximately 30 tons of bamboo wood can be produced from 1 ha, six tons of charcoal can be produced from a unit ha of bamboo forest. The chemical analyses provided in various studies suggest that less than $4 \%$ of ash is present in bamboo after pyrolysis. The major ash composition includes $\mathrm{K}_{2} \mathrm{O}, \mathrm{SiO}_{2}$, and $\mathrm{P}_{2} \mathrm{O}_{5}$, which are also present in coal that is employed in the steel industry in considerably higher quantities. Coal that is employed for PCI significantly varies; thus, an average value from previously published references has been applied, in which $\mathrm{SiO}_{2}$ and $\mathrm{Al}_{2} \mathrm{O}_{3}$ constitute approximately $60 \%$ of the total ash content and $20 \%$ of the average as-received coal weight. Thus, coal contains five times the amount of ash than bamboo charcoal.

If the PCI in the BF is substituted with the carbon neutral bamboo charcoal, which has similar calorific value of approximately $3000 \mathrm{kcal} / \mathrm{kg}, 150 \mathrm{~kg}$-coal/ton-hot metal could be replaced. These changes would cause a potential decrease in $\mathrm{CO}_{2}$ of approximately $440 \mathrm{~kg}-\mathrm{CO}_{2} /$ ton-hot metal. In addition to the substitution by the carbon neutral charcoal, acidic oxides of $\mathrm{SiO}_{2}$ and $\mathrm{Al}_{2} \mathrm{O}_{3}$ of approximately $18 \mathrm{~kg}$ /ton-hot metal will also decrease. Because the fluidity of the slag in the $\mathrm{BF}$ must be maintained by the addition of $\mathrm{CaO}$ at a fixed $\mathrm{CaO} / \mathrm{SiO}_{2}$ ratio of approximately 1.3 , the substitution by charcoal will decrease the slag amount by $41.4 \mathrm{~kg} /$ ton-hot metal. This decrease in slag amount will subsequently decrease the carbon that is consumed in the BF by approximately $7 \mathrm{~kg}$ /ton-hot metal, which would correspond to $26 \mathrm{~kg}-\mathrm{CO}_{2} /$ ton-hot metal. Thus, the substitution of the PCI with bamboo charcoal would correspond to a decrease in the $\mathrm{CO}_{2}$ emissions in the blast furnace by $466 \mathrm{~kg}-\mathrm{CO}_{2} /$ ton-hot metal. According to WSA statistics [9], 41 million tons of total hot metal were produced in Korea in 2013, which represents an annual $\mathrm{CO}_{2}$ reduction of approximately 19 million tons. Figure 7 a estimates the possible $\mathrm{CO}_{2}$ reduction from the substitution of PCI in the BF with various amounts of bamboo charcoal. Using the ARIMA model and assuming a 50\% substitution of the PCI with bamboo wood charcoal and a neutralization capacity of 38 ton- $\mathrm{CO}_{2} /$ ha, the effect of bamboo wood charcoal for the basic metals $\mathrm{CO}_{2}$ neutralization was forecasted to 2030 using the ARIMA model. The average increase in $\mathrm{CO}_{2}$ emissions of the basic metals industry during the forecasted time range to 2030 was $10 \%$ on average based on the emissions between 2010 and 2014; this estimate was employed for the forecasted values applied in the ARIMA model. The results in Figure $7 \mathrm{~b}$ indicate that the large slope of the decrease in the eco- $\mathrm{CO}_{2}$ index has been significantly deflected and the neutralization ability can be maintained at approximately $13 \%$ in 2030, even with the expected industry expansion forecasted by the ARIMA model by substituting PCI with bamboo wood charcoal and the bamboo farming of 50,000 ha. 


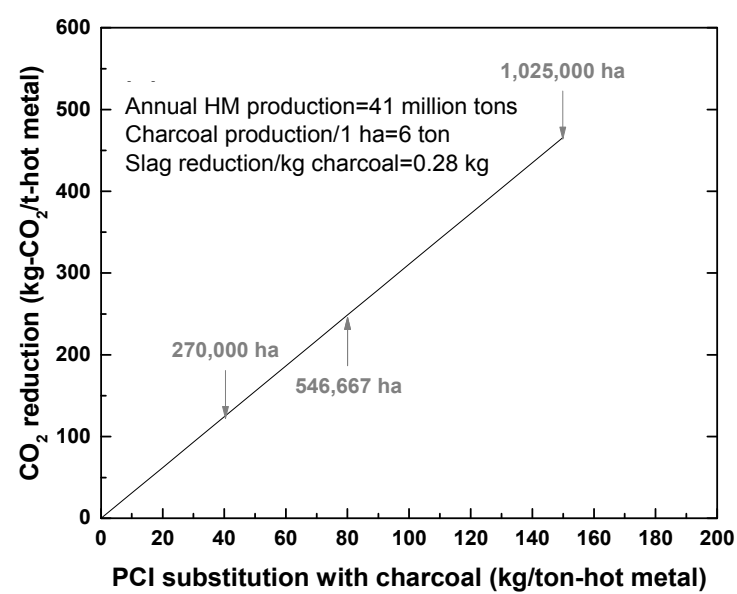

(a)

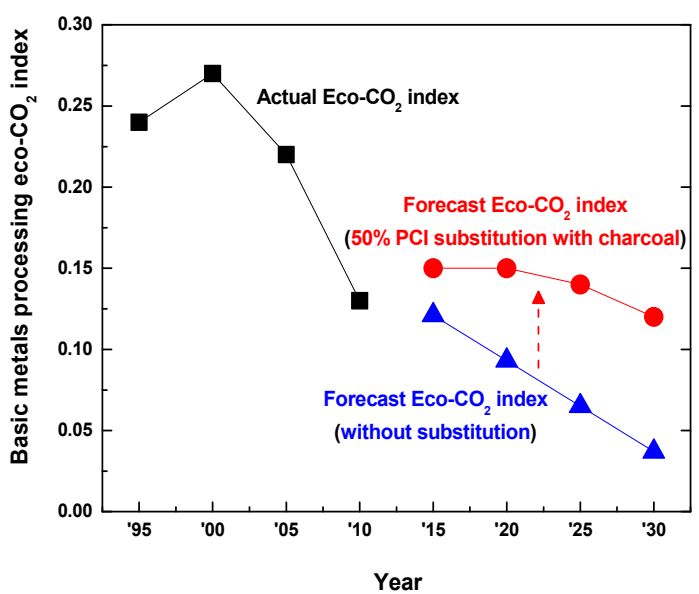

(b)

Figure 7. Estimation of (a) the $\mathrm{CO}_{2}$ reduction potential after substitution of PCI within the BF using bamboo charcoal and $(\mathbf{b})$ the basic metals processing eco- $\mathrm{CO}_{2}$ index with $\mathrm{PCI}$ substitution of $50 \%$ with farmed bamboo wood charcoal in the BF.

\section{Conclusions}

The environmental issues caused by GHG emissions resonate beyond a specific industry to countries and the world over. This study has investigated changes in $\mathrm{CO}_{2}$ emissions and the consumption of various energy sources, namely, coal/peat, oil, and electricity. This study focused on an industry with significant $\mathrm{CO}_{2}$ emissions because a comprehensive analysis of all industry sectors was not feasible.

First, using the distribution structure of the input-output table, the corresponding energy sources were correlated and the direct and indirect $\mathrm{CO}_{2}$ emissions were estimated. An increase in the direct $\mathrm{CO}_{2}$ emissions indicates an increase in the use of the energy sources from the steel and metals industry that cause direct emissions. An increase in the indirect $\mathrm{CO}_{2}$ emissions suggests an increase in the utilization of electricity in the steel and metals industry. From the analysis of five countries, namely, Korea, China, US, Japan, and Germany, the direct $\mathrm{CO}_{2}$ emissions increased more than 1.4 times in 2010 and the indirect $\mathrm{CO}_{2}$ emissions increased more than two times in 2010 compared to 1995 values. These trends were more apparent in China, with direct and indirect $\mathrm{CO}_{2}$ emissions of 908.34 million tons in 2010 and 155.73 million tons in 2010, respectively. Second, the elasticity was calculated to identify the effect of input energy costs on the $\mathrm{CO}_{2}$ emissions and the sensitivity to a particular energy source. The results suggest that Korea, Japan, and Germany are $\mathrm{CO}_{2}$-sensitive to the "electricity, gas and supply (16)" energy sources, whereas China and the US are more sensitive to the "mining and quarrying (2)" energy sources.

In addition, the forest areas of the individual countries were employed to calculate the potential neutralization ability of the emitted $\mathrm{CO}_{2}$. According to 2010 data, the US had the highest neutralization ability $(66.1 \%)$, whereas Korea had the lowest neutralization ability $(15 \%)$. Future estimates and trends of the neutralization ability indicated that China and Korea are rapidly losing their neutralization ability; if the current state of the forest area is maintained, a negative neutralization ability will result. Thus, efforts to curtail this significant loss of neutralization ability must be implemented in both China and Korea with the planting and farming of $\mathrm{CO}_{2}$-absorbing trees for industry sustainability. Using fast-growing bamboo trees as a source for carbon neutral wood charcoal, the substitution of $50 \%$ $\mathrm{PCI}$ in the BF process indicated a significant improvement of the eco- $\mathrm{CO}_{2}$ index without significant industry contraction.

Although the analysis in this study focused on 20-year-old trees, only approximately $3.33 \%$ of the trees in Korea are 30 years old or younger, $19.66 \%$ of these trees are within $31-40$ years and $77.01 \%$ of the trees in Korea are at least 41 years old. Thus, the neutralization ability may be less than the $15 \%$ presented in this study, which highlights the need to rapidly implement regulations to plant and farm broad-leaf trees with increased $\mathrm{CO}_{2}$ absorption capacities. 
Acknowledgments: This study was partially supported by the Brain Korea 21 PLUS (BK21 PLUS) Project at the Division of the Eco-Humantronics Information Materials and the National Research Foundation of Korea Grant (NRF-2016K2A9A2A08003672). This work was performed while Project Associate Professor at the Graduate School of Frontier Sciences at The University of Tokyo in Chiba, Japan.

Author Contributions: Kyunsuk Choi provided statistical data and verification of the OECD information and correlated with the $\mathrm{CO}_{2}$ intensity, Hiroyuki Matsuura verified the data of Japan and provided feedback on potential sustainable technologies in ironmaking, Hyunjoung Lee and Il Sohn have equal contributions as corresponding author and overall completed the manuscript through data interpretation, calculations, and estimations through the ARIMA analysis.

Conflicts of Interest: The authors declare no conflict of interest.

\section{References}

1. Rosenzweig, C.; Iglesias, A.; Yang, X.B.; Epstein, P.R.; Chivian, E. Climate change and extreme weather events-Implications for food production, plant diseases, and pests. Glob. Chang. Hum. Health 2001, 2, 90-104. [CrossRef]

2. UN Framework Convention on Climate Change: Kyoto Protocol to the United Nations Framework Convention on Climate Change. United Nations 1998. Available online: http://unfccc.int/resource/ docs/convkp/kpeng.pdf (accessed on 15 June 2015).

3. UN Framework Convention on Climate Change: Report of the Conference of the Parties on its Fifteenth Session, Held in Copenhagen from 7 to 19 December 2009. Available online: http:/ / unfccc.int/resource/ docs/2009/cop15/eng/11a01.pdf (accessed on 15 June 2015).

4. IEA. Energy Statistics of OECD Countries 2014. Available online: http://www.oecd-ilibrary.org/energy/ energy-balances-of-oecd-countries-2014_energy_bal_oecd-2014-en (accessed on 10 April 2015).

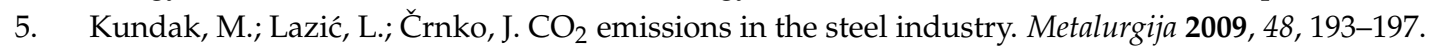

6. Lee, B.; Sohn, I. Review of innovative energy savings technology for the electric arc furnace. JOM 2014, 66, 1581-1594. [CrossRef]

7. Hasanbeigi, A.; Arens, M.; Price, L. Alternative emerging ironmaking technologies for energy-efficiency and carbon dioxide emissions reduction: A technical review. Renew. Sust. Energ. Rev. 2014, 33, 645-658. [CrossRef]

8. Ho, M.T.; Bustamente, A.; Wiley, D.E. Comparison of $\mathrm{CO}_{2}$ capture economics for iron and steel mills. Int. J. Greenh. Gas. Control. 2013, 19, 145-159. [CrossRef]

9. World Steel Association. Steel Statistical Yearbook. Available online: http://www.worldsteel.org/statistics/ statistics-archive/yearbook-archive.html (accessed on 15 June 2015).

10. Su, B.; Ang, B.W. Input-output analysis of $\mathrm{CO}_{2}$ emissions embodied in trade: A multi-region model for China. Appl. Energ. 2014, 114, 377-384. [CrossRef]

11. Su, B.; Ang, B.W. Multi-region input-output analysis of $\mathrm{CO}_{2}$ emissions embodied in trade: The feedback effects. Ecol. Econ. 2011, 71, 42-53. [CrossRef]

12. Li, L.; Lei, Y.; Pan, D. Study of $\mathrm{CO}_{2}$ emissions in China's iron and steel industry based on economic input-output life cycle assessment. Nat. Hazards 2016, 81, 957-970. [CrossRef]

13. Hetherington, R. An input-output analysis of carbon dioxide emissions for the UK. Energy Convers. Mgmt. 1996, 37, 979-984. [CrossRef]

14. Chen, G.Q.; Zhang, B. Greenhouse gas emissions in China 2007: Inventory and input-output analysis. Energy Policy 2010, 38, 6180-6193. [CrossRef]

15. Chang, Y.F.; Lewis, C.; Linc, S.J. Comprehensive evaluation of industrial $\mathrm{CO}_{2}$ emission (1989-2004) in Taiwan by input-output structural decomposition. Energy Policy 2008, 36, 2471-2480. [CrossRef]

16. Leontief, W. Input-Output Economics; Oxford University Press: New York, NY, USA, 1986.

17. OECD. Input-Output Total Tables. Available online: http://stats.oecd.org/Index.aspx?DataSetCode=IOTS (accessed on 8 March 2015).

18. The Bank of Korea. Economic Statistics System. Input-Output Tables. Available online: https://ecos.bok.or. $\mathrm{kr} /$ (accessed on 8 March 2015).

19. National Bureau of Statistics of China. China Statistical Yearbook 2013. 2010 Input-Output Table. Available online: http://www.stats.gov.cn/tjsj/ndsj/2013/indexeh.htm (accessed on 5 March 2015). 
20. Bureau of Economic Analysis of US. Input-Output Accounts Data. Available online: http://www.bea.gov/ industry/io_annual.htm (accessed on 8 March 2015).

21. Ministry of Economy, Trade and Industry of Japan. Updated Input-Output Table. Input-Output Table and Inverse Matrix. Available online: http:/ /www.meti.go.jp/english/statistics/typ/entyoio/index.html (accessed on 8 March 2015).

22. Statistisches Bundesamt of Germany. Input-Output Accounts. Available online: https://wwwgenesis.destatis.de/genesis/online/data;jsessionid=1416F59B01AA01A3C0093BBB5A7BBCAA.tomcat_ GO_1_2?operation=abruftabelleBearbeiten\&levelindex=2\&levelid=1463226917336\&auswahloperation= abruftabelleAuspraegungAuswaehlen\&auswahlverzeichnis=ordnungsstruktur\&auswahlziel=werteabruf\& selectionname=81511-0002\&auswahltext=\&werteabruf=Value+retrieval (accessed on 8 March 2015).

23. World Input-Output Database. Available online: http://www.wiod.org/new-site/database/wiots.htm (accessed on 8 March 2015).

24. Su, B.; Ang, B.W. Input-output analysis of $\mathrm{CO}_{2}$ emissions embodied in trade: Competitive versus non-competitive imports. Energy Policy 2013, 56, 83-87. [CrossRef]

25. Su, B.; Huang, H.C.; Ang, B.W.; Zhou, P. Input-output analysis of $\mathrm{CO}_{2}$ emissions embodied in trade: The effects of sector aggregation. Energy Econ. 2010, 32, 166-175. [CrossRef]

26. Curtis, P.S.; Wang, X.A. Meta-analysis of elevated $\mathrm{CO}_{2}$ effects on woody plant mass, form, and physiology. Oecologia 1998, 113, 299-313. [CrossRef]

27. Norby, R.J.; Wullschleger, S.D.; Gunderson, C.A.; Johnson, D.W.; Ceulemans, R. Tree responses to rising $\mathrm{CO}_{2}$ in field experiments: Implications for the future forest. Plant. Cell. Environ. 1999, 22, 683-714. [CrossRef]

28. Smith, S.D.; Huxman, T.E.; Zitzer, S.F.; Charlet, T.N.; Housman, D.C.; Coleman, J.C.; Fenstermaker, L.K.; Seemann, J.R.; Nowak, R.S. Elevated $\mathrm{CO}_{2}$ increases productivity and invasive species success in an arid ecosystem. Nature 2000, 408, 79-82. [CrossRef] [PubMed]

29. The World Bank. Forest Area (\% of Land Area). Available online: http://data.worldbank.org/indicator/AG. LND.FRST.ZS (accessed on 15 June 2015).

30. Korea Forest Service. The Amount of Carbon Absorbed by Trees 2013. Available online: http:/ / www.forest.go.kr/newkfsweb/cop/bbs/selectBoardArticle.do?bbsId=BBSMSTR_1036\&mn=KFS_ 03_02_01\&nttId=2882053 (accessed on 15 June 2015). (In Korean).

31. The United Nation Food and Agriculture Organization. Global Forest Resources Assessment 2010. Available online: http://www.fao.org/docrep/013/i1757e/i1757e.pdf (accessed on 15 June 2015).

32. Dowdy, S.M.; Wearden, S. Statistics for Rsearch; Wiley: New York, NY, USA, 1983.

33. Stockholm International Peace Research Institute: Military Expenditure Database. Available online: http:/ / www.sipri.org (accessed on 15 June 2015).

34. Cox, P.M.; Betts, R.A.; Jones, C.D.; Spall, S.A.; Totterdell, I.J. Acceleration of global warming due to carbon-cycle feedbacks in a coupled climate model. Nature 2000, 408, 184-187. [CrossRef] [PubMed]

35. Hilker, T.; Lyapustin, A.I.; Tucker, C.J.; Hall, F.G.; Myneni, R.B.; Wang, Y.; Bi, J.; de Moura, Y.M.; Sellers, P.J. Vegetation dynamics and rainfall sensitivity of the Amazon. Proc. Natl. Acad. Sci. USA 2014, 111, 16041-16046. [CrossRef] [PubMed]

36. Asteriou, D.; Hall, S.G. Applied Econometric; Palgrave Macmillan: Basingstoke, UK, 2011.

37. Maoyi, F.; Xiaosheng, Y.; Shenxue, J. Technical Manual on Utilization of Sympodial Bamboos; China Forestry Publishing House: Beijing, China, 2007.

38. Scurlock, J.M.O. Bamboo: An Overlooked Biomass Resource? Oak Ridge National Laboratory Environmental Sciences Division Report. Biomass Bioenergy 2000, 19, 229-244. [CrossRef]

39. Bahtiar, E.T.; Nugroho, N.; Carolina, A.; Maulana, A.C. Measuring carbon dioxide sink of betung bamboo (Dendrocallamus asper (Schult f.) Backer ex Heyne) by sinusoidal curves fitting on its daily photosynthesis light response. J. Agric. Sci. Technol. B 2012, 2, 780-788.

40. Thokchom, A.; Yadava, P.S. Bamboo and its role in climate change. Curr. Sci. 2015, 108, 762-763.

41. Ogawa, K.; Hirogaki, K.; Aoyama, E.; Taniguchi, M.; Ogawa, S. Sustainable manufacturing system focusing on the natural growth of bamboo. J. Adv. Mech. Des. Syst. Manuf. 2010, 4, 531-542. [CrossRef]

(C) 2016 by the authors; licensee MDPI, Basel, Switzerland. This article is an open access article distributed under the terms and conditions of the Creative Commons Attribution (CC-BY) license (http://creativecommons.org/licenses/by/4.0/). 